\title{
Marine Fish Marketing and Prices Changes in Different Levels of Market in Bangladesh: An Empirical Study Using Primary Data
}

\author{
Md. Golam Rabbani ${ }^{1}$, M. Serajul Islam ${ }^{2}$ and Rozina Yeasmin Lucky ${ }^{1}$ \\ ${ }^{1}$ Department of Economics, Hajee Mohammad Danesh Science and Technology University, Dinajpur, \\ Bangladesh; ${ }^{2}$ Department of Agricultural Economics, Bangladesh Agricultural University, \\ Mymensingh \\ *Corresponding author and Email: grabbanihstu@yahoo.com
}

Received: 3 May 2017

Accepted: 22 December 2017

\begin{abstract}
Contribution of fisheries in the national economy of Bangladesh is substantial, particularly with reference to food consumption, nutrition, employment and export. The present study was designed to determine the changes of prices of marine fish at different levels of market and to determine various problems relating to marine fish marketing system in Bangladesh. This study used purposive sampling and data were collected from 168 stakeholders using interview schedule considering 10 major species of marine fish during 2014. Primary, secondary and consumer market were considered in the study. The study revealed that both marketing margins as well as marketing profit are relatively higher in consumer market followed by primary and secondary markets, where baparis and aratders are involved. Marketing costs for per kg of marine fish were estimated to be Tk 8.55, 1.10 and 4.50 for beparis, aratdars and retailers, respectively. Average marketing cost was lower in primary market (Tk $8.86 / \mathrm{kg}$ ) compared to secondary market (Tk 9.99/kg) and consumer market (Tk 12.29/kg). The marketing system of marine fish in Bangladesh is yet to be developed and since this is facing a lot of problems including post-harvest losses, poor physical facilities, etc. Government and department of fisheries should take necessary action for development of marketing system of marine fishes.
\end{abstract}

Keywords: Marine fish, marketing cost, marketing margin, Bangladesh.

\section{Introduction}

Fish is the most important animal source of food in Bangladesh, accounting for more than $60 \%$ of total animal protein intake (DoF, 2014). Households Income and Expenditure Survey (HIES, 2010) found that in two-weeks period more than $98 \%$ of respondents consumed fish at least once per week, and $60 \%$ at least every alternate day .The marine fisheries sector has been recognized as an important part of the economy of Bangladesh. Fish production from the Bay of Bengal (BoB) has increased marginally over the last 10 years but its relative share in total fish production has declined (Hossain et al., 2010). Bangladesh's coastal waters contain diverse fisheries resources, with 475 species of finfish including the cartilaginous fishes - sharks, skates and rays (Mazid, 2005). Fishing, in the absence of proper information on the status of stock, is leading to over-exploitation of inshore and under exploitation of offshore fishery resources and micronutrients for the poor (Minkin et al., 1997; Kawarazuka and Béné 
2010, 2011; Roos et al., 2007). If the growth of this sector is hindered, it is not only going to affect the livelihoods of a large number of rural populations but it also affects the nutrition of many poor households.

The fishery market is one of the world's fastest growing international commodity markets. For developing countries, fishery products export generates more revenue than the combined earnings from other agricultural exports such as coffee, bananas, rice and tea. But fisheries production and yield are constrained by various factors. Without research on these constraints, any decision could generate inefficiency. Various control measures (like, input control and output control) have been considered in fisheries management to maintain the target species at or above levels necessary to ensure their continued productivity (Chowduary, 2010).

Again in terms of volume, the marine fish market in Bangladesh is large (Ahmed et al., 1993). The fish marketing system is traditional, complex and less competitive but plays a vital role in connecting the fishermen and consumers, thus contributing significantly in the "value adding" process which otherwise would have been unused or underused and consequently in the earning of the fisher folk (Chowduary, 2004). In Bangladesh the market for fish is associated with strong demand driven by continued increase in rural and urban population (Chowduary, 2010). Fish play an important role for the population of Bangladesh as indicated by the proverb "Mache Bhate Bangali" (fish and rice make a Bengali). However, fish consumption appears to have fallen marginally because fish prices have been increasing faster than prices of other commodities (Islam and Elahi, 1994).

Bangladesh is endowed with vast marine, brackish and inland waters having great fisheries potentials. It has $720 \mathrm{~km}$ in coastal line along southern part of the country facing Bay of Bengal. The total marine water area of country is $1,66,000$ square kilometer of which continental shelf area is 66,440 square kilometer (BBS,
2015). The marine waters are rich in nutrient creating suitable habitat of fish production. Fishing communities face multiple problems involving social, economic, institutional, technical, infrastructural and even ethnic factors. Many of NGOs are already active supporting groups of fishermen and fish farmers to solve some of these problems in different parts of the country. Encouraging effects can be seen in the performance of NGOs such as BRAC (Bangladesh Rural advancement Committee), BRDB (Bangladesh Rural Development Board), PROSHIKA and CARITAS in forming functional groups in fishing communities.

The present study was therefore designed to examine the changes of prices of marine fish at different levels of market and various problems relating to marine fish marketing system in Bangladesh.

\section{Materials and Methods}

\subsection{Area selection, data source and collection}

The study was based on both primary and secondary data. Primary data on marine fish marketing were collected through questionnaire survey. A total of 8 FGDs were also conducted to have detailed information about marketing system of marine fish during the year 2014. A purposive sampling technique was used for sample selection. For marketing and distribution of marine fish, 168 traders (42 aratdars, 56 beparies and 70 retailers) were selected from the primary, secondary and consumer market at different location of Bangladesh. ${ }^{1}$

\subsection{Analytical technique}

The collected data and information were coded, tabulated, compiled and analyzed considering the

\footnotetext{
${ }^{1}$ The primary markets were Cox's Bazar, Chittagong and Khulna. Secondary markets were; Cox's Bazar, Chittagong, Khulna, Dhaka and Rangpur, and the consumer markets were Cox's Bazar, Chittagong, Khulna, Dhaka Rangpur and Mymensingh.
} 
objectives of the study. Tables were prepared using arithmetic mean, percentage and ratio.

\subsubsection{Marketing cost}

Marketing cost is the sum of transport cost, storage cost, labour cost and other costs associated with moving the commodity from the point of purchase to the customer or final consumer. The total marketing cost was determined by the following formula:

$$
T c=C p+\sum M c i
$$

Where,

$\mathrm{i}=1,2,3----n, \mathrm{Tc}=$ Total cost of marketing, $\mathrm{Cp}=$ Producer cost of marketing, Mci= Marketing cost by the ith trader

\subsubsection{Marketing margin}

According to Kohls and Uhl (2005), marketing margin in a sense is the price of all utility adding activities and functions that are performed by the intermediaries. Marketing margin at a particular stage of transaction is the difference between sales price and purchase price. A marketing margin is the percentage of the final weighted average selling price taken by each stage of the marketing chain. The margin must cover the costs involved in transferring produce from one stage to the next and provide a reasonable return to those doing the marketing activities (Crawford, 1997).

However, marketing cost and marketing margin of respective categories of intermediaries are the main determinants of the profitability in marketing of marine fish. Secondly, marketing margin of a particular level of market is greatly influenced by the supply of and demand for fish marketed. At each level of market, most of the intermediaries act as buyers and as well as sellers. Accordingly, their market margins depend on market condition in the time of buying and selling.

The absolute margin of the middleman, wholesaler, trader and retailers were determined as follows:

$$
M m=P s a-(P b a+M c)
$$

Where,

$M m=$ Marketing margin, $P s a=$ Selling price,

$P b a=$ Buying price, $M c=$ Marketing cost

\section{Results and Discussion}

\subsection{Marketing cost and margin}

As shown in Table 1 that mainly three types of intermediaries' viz., beparis, aratdars and retailers were found to be involved in marine fish marketing. These three categories of intermediaries perform different marketing operations and functions; however, there is a large variation in marketing cost incurred by the intermediaries. Among all cost items incurred by different stakeholders, transportation cost was the highest $(36.33 \%)$ followed by aratdars commissions (30.13\%). After purchasing fish from landing station, beparis carry it by trucks to inter-district markets and they perform the marketing functions of assembling, icing and loading and unloading. They also pay aratdar's commission, electricity and rent for arat houses. Beparis sell their fish to the retailers through aratdars and they have to pay 3 to $4 \%$ commission to aratdar from their sales revenue.

It may be noted here that payment of commission makes the marketing cost higher for beparis than for retailers. However, marketing costs for each $\mathrm{kg}$ of marine fish were estimated to be Tk 8.55, Tk 1.10 and Tk 4.50 for beparis, aratdars and retailers, respectively (Table 1). In lieu for taking commission, aratdars simply help beparis to sell their products and collect buyers (retailers) to purchase it without taking any risk of loss or damage of fish. Accordingly, aratdar's marketing cost was lower (Tk $1.10 / \mathrm{kg}$ ) compared to that of beparis and retailers. It may be noted that faria and inter-district aratdar agents are associated with beparis and perform the marketing function.

Species-wise average marketing costs of marine fish marketing in different locations are shown in Table2. Table reveals that there is small variation in marketing cost at different locations of primary market. Considering all selected species, 
cost of marketing was almost similar in all the locations for each level of market but there was small variation of marketing cost among the species studied. However, average marketing cost was lower in primary market (Tk $8.86 / \mathrm{kg}$ ) compared to secondary market (Tk $9.99 / \mathrm{kg}$ ) and consumer market (Tk 12.29/kg) (Table 2). Again, considering the involvement of stakeholders, fishermen and faria are involved in primary market; aratdar and bepari in secondary market; and those of inter-district aratdar agent and retailers are involved in consumer market and they shared about $30 \%, 31 \%$ and $39 \%$ of total marketing cost, respectively (Table 1). Even in case of individual species, small variation was observed for marketing cost and as well as sales price both in secondary market and consumer market. However, for marine fish, consumer market and secondary market were competitive compared to primary market (Islam et al 2001).

Marketing margins and profitability of different intermediaries were estimated separately and are shown in Tables 3. Results are presented for individual species and average of all selected species. Total marketing margin and marketing profit are also estimated for easy understanding and presentation.

Table 1. Total marketing cost of stakeholders and intermediaries involved in major species of marine fish $(\mathrm{Tk} / \mathrm{kg})$

\begin{tabular}{|c|c|c|c|c|c|c|c|c|}
\hline Cost items & 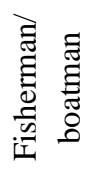 & $\cdot \frac{\pi}{\vec{Z}}$ & 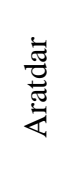 & : & $\begin{array}{l}\text { Inter- } \\
\text { district } \\
\text { aratdar } \\
\text { lagent }\end{array}$ & 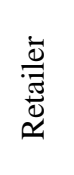 & 胥 & $\begin{array}{l}\text { 포 } \\
0 \\
0 \\
0 \\
0 \\
0\end{array}$ \\
\hline $\begin{array}{l}\text { Transportation, } \\
\text { loading/unloading }\end{array}$ & 1.27 & 1.63 & 0.00 & 3.01 & 3.30 & 1.56 & 10.77 & 36.33 \\
\hline Landing station tolls & 0.25 & 0.25 & 0.00 & 0.25 & 0.00 & 0.00 & 0.75 & 2.53 \\
\hline Baskets & 0.00 & 0.13 & 0.05 & 1.01 & 0.00 & 0.41 & 1.59 & 5.37 \\
\hline Icing & 0.00 & 0.00 & 0.00 & 1.26 & 0.00 & 0.81 & 2.07 & 6.97 \\
\hline Wage and salaries & 0.00 & 0.17 & 0.57 & 0.17 & 0.39 & 0.00 & 1.30 & 4.37 \\
\hline $\begin{array}{l}\text { Aratdar's } \\
\text { commission }\end{array}$ & 2.39 & 2.13 & 0.00 & 2.36 & 2.06 & 0.00 & 8.93 & 30.13 \\
\hline House rent & 0.00 & 0.00 & 0.14 & 0.03 & 0.01 & 0.56 & 0.74 & 2.48 \\
\hline Security & 0.00 & 0.00 & 0.01 & 0.00 & 0.00 & 0.05 & 0.06 & 0.20 \\
\hline Electricity & 0.00 & 0.00 & 0.01 & 0.00 & 0.01 & 0.13 & 0.15 & 0.52 \\
\hline Telephone bill & 0.11 & 0.10 & 0.13 & 0.16 & 0.08 & 0.31 & 0.88 & 2.97 \\
\hline Personal expenses & 0.08 & 0.11 & 0.17 & 0.20 & 0.16 & 0.47 & 1.19 & 4.02 \\
\hline Tips and donation & 0.13 & 0.11 & 0.02 & 0.12 & 0.03 & 0.05 & 0.45 & 1.50 \\
\hline Wastage & 0.00 & 0.00 & 0.00 & 0.00 & 0.52 & 0.00 & 0.52 & 1.75 \\
\hline Others & 0.00 & 0.00 & 0.01 & 0.00 & 0.09 & 0.16 & 0.26 & 0.86 \\
\hline Total & $\begin{array}{l}4.23 \\
(14)\end{array}$ & $\begin{array}{l}4.63 \\
(16)\end{array}$ & $\begin{array}{l}1.10 \\
(3)\end{array}$ & $\begin{array}{l}8.55 \\
(28)\end{array}$ & $\begin{array}{l}6.63 \\
(22)\end{array}$ & $\begin{array}{l}4.50 \\
(17)\end{array}$ & $\begin{array}{l}29.64 \\
(100)\end{array}$ & 100.00 \\
\hline
\end{tabular}

Source: Field survey 2014, Note: Figures within parenthesis indicate percent of total marketing cost. 
Tables 3 show that like individual species, marketing margin were relatively higher in consumer market (Tk. 40/kg) followed by secondary (Tk. 28/kg) and primary markets (Tk. $32 / \mathrm{kg}$ ) where beparies and aratdars are involved and marketing profit were higher in secondary marked followed by consumer market and primary market. It is evident from the above mentioned tables that high priced fish demanded high marketing cost resulting higher marketing margin and profit compared to low priced fish. It was reported that processing and transportation costs were higher for high valued species compared to the low valued ones.

Considering all major species in marine fish market the average marketing margins for each $\mathrm{kg}$ of fish were Tk 31.68, Tk 38.44 and Tk 40.10 in primary, secondary and consumer markets, respectively and the corresponding values for profits for three different markets were Tk 22.82, Tk 28.45 and Tk 27.81, respectively. Adding up the average values of marketing margin and profits at different levels of market, total marketing margin and profit were Tk 110.22 and 79.08 per kg, respectively (Table 3 ).

\subsection{Marketing problems and constraint}

Marine fishing communities face multiple problems involving social, economic, institutional, technical, infrastructural and even ethnic factors (Table 4). Many NGOs are already actively supporting groups of fishermen and fish traders to solve some of these problems in coastal areas and various parts of the country. However, broadly the problems of marine fish marketing were as follows:

\subsubsection{Post-harvest losses}

In Bangladesh, the fisheries sector suffers from serious post-harvest losses every year due to ignorance and negligence in handling and processing at different stages of the supply chain from the harvest to retail distribution. It is believed that about $30-33 \%$ of all fish caught becomes unfit for human consumption. Improper handling and processing reduce the quality of the products. Eighty four percent respondents reported that post-harvest loss is a serious problem in the marine fish supply chain (Table 4).

\subsubsection{Poor physical facilities}

The Bangladesh Fisheries Development Corporation (BFDC) operates six fish landing centers in the coastal districts namely, Chittagong, Cox's Bazar, Khulna, Barisal, Patherghata and Khepupara. All these centers are provided with landing platforms, auction halls, ice plants, cold storage, drinking water and accommodation for fish traders. The only fish harbor in the country developed by BFDC is located at Chittagong, near to Chittagong port, on the north side of the Karnaphuli River. The fish landing centers is very limited in respect to coastal areas. Fishermen operating small traditional craft usually land their catch on the coast. Seventy three percent respondents feel the shortages of fish landing centers and it's a major problem in marine fish distribution system.

\subsubsection{Poor transport system}

Most of the marine catches are marketed fresh. Some are frozen for export, some are dried and a small portion is salted. The transport facilities are very poor and remarkable portions of the catch are spoiled due to lack of quick and better transport facilities as fish is the most perishable product. Within very short time fish are spoiled and its quality also deteriorated. Low quality fish is of great concern to food security and public health. It also results in serious economic loss for the fish traders and processors. Sixty eight percent respondents claim that a poor transportation system is another major problem for marine fish marketing.

\subsubsection{Inadequate facilities of wholesale and retail market}

Wholesale fish markets are not well developed. Wholesale fish market run by the fish traders are of very poor standard and need improvement. In most cases there are no auction sheds, no packing sheds, no landing terminals, no gangways, no pontoons and no proper drainage or hygienic facilities. 
Table 3. Marketing margin and profitability of different major species of marine fish in different locations (Tk./Kg.)

\begin{tabular}{|c|c|c|c|c|c|c|c|c|c|c|c|}
\hline \multirow{2}{*}{ Particulars of marketing } & \multicolumn{11}{|c|}{ Major Species (Tk/Kg) } \\
\hline & Hilsa & Pomfret & $\begin{array}{l}\text { Cat } \\
\text { fish }\end{array}$ & $\begin{array}{c}\text { Bombay } \\
\text { duck }\end{array}$ & $\begin{array}{l}\text { Ribbon } \\
\text { fish }\end{array}$ & Coral & Paisa & Surma & $\begin{array}{l}\text { Captured } \\
\text { shrimp }\end{array}$ & $\begin{array}{l}\text { Bomb } \\
\text { maitta }\end{array}$ & $\begin{array}{c}\text { All } \\
\text { species }\end{array}$ \\
\hline \multicolumn{12}{|l|}{ Primary market } \\
\hline Purchase price $(\mathrm{PP})$ & 524.58 & 610.00 & 208.75 & 106.00 & 129.07 & 410.94 & 97.08 & 246.67 & 180.83 & 126.25 & 264.02 \\
\hline Marketing cost (MC) & 9.15 & 8.94 & 8.83 & 8.75 & 8.82 & 8.77 & 8.79 & 8.90 & 8.84 & 8.79 & 8.86 \\
\hline Sales price (SP) & 587.53 & 683.20 & 233.80 & 118.72 & 144.55 & 460.26 & 108.73 & 276.27 & 202.53 & 141.40 & 295.70 \\
\hline Marketing margin (MM=SP-PP) & 62.95 & 73.20 & 25.05 & 12.72 & 15.49 & 49.31 & 11.65 & 29.60 & 21.70 & 15.15 & 31.68 \\
\hline Marketing profit (MP=MM-MC) & 53.80 & 64.26 & 16.22 & 3.97 & 6.67 & 40.54 & 2.86 & 20.70 & 12.86 & 6.36 & 22.82 \\
\hline \multicolumn{12}{|l|}{ Secondary market } \\
\hline Purchase price(PP) & 587.53 & 683.20 & 233.80 & 118.72 & 144.55 & 460.26 & 108.73 & 276.27 & 202.53 & 141.40 & 295.70 \\
\hline Marketing cost (MC) & 10.22 & 10.04 & 9.97 & 9.96 & 9.92 & 10.00 & 9.90 & 9.95 & 9.97 & 10.00 & 9.99 \\
\hline Sales price (SP) & 663.91 & 772.02 & 264.19 & 134.15 & 163.35 & 520.09 & 122.87 & 312.18 & 228.86 & 159.78 & 334.14 \\
\hline Marketing margin (MM=SP-PP) & 76.38 & 88.82 & 30.39 & 15.43 & 18.79 & 59.83 & 14.14 & 35.91 & 26.33 & 18.38 & 38.44 \\
\hline Marketing profit (MP=MM-MC) & 66.16 & 78.78 & 20.42 & 5.47 & 8.87 & 49.83 & 4.24 & 25.97 & 16.36 & 8.39 & 28.45 \\
\hline \multicolumn{12}{|l|}{ Consumer market } \\
\hline Purchase price (PP) & 663.91 & 772.02 & 264.19 & 134.15 & 163.35 & 520.09 & 122.87 & 312.18 & 228.86 & 159.78 & 334.14 \\
\hline Marketing cost (MC) & 12.52 & 12.39 & 12.29 & 12.19 & 12.17 & 12.32 & 12.20 & 12.28 & 12.27 & 12.26 & 12.29 \\
\hline Sales price (SP) & 743.58 & 864.66 & 295.90 & 150.25 & 182.95 & 582.50 & 137.61 & 349.64 & 256.33 & 178.96 & 374.24 \\
\hline Marketing margin (MM=SP-PP) & 79.67 & 92.64 & 31.70 & 16.10 & 19.60 & 62.41 & 14.74 & 37.46 & 27.46 & 19.17 & 40.10 \\
\hline Marketing profit (MP=MM-MC) & 67.15 & 80.25 & 19.42 & 3.91 & 7.43 & 50.09 & 2.54 & 25.18 & 15.19 & 6.91 & 27.81 \\
\hline \multicolumn{12}{|l|}{ Total marketing margin and profit } \\
\hline Total marketing margin & 219.00 & 254.66 & 87.15 & 44.25 & 53.88 & 171.56 & 40.53 & 102.98 & 75.49 & 52.71 & 110.22 \\
\hline Total marketing profit & 187.11 & 223.29 & 56.05 & 13.35 & 22.97 & 140.46 & 9.64 & 71.85 & 44.41 & 21.66 & 79.08 \\
\hline
\end{tabular}

Source: Field survey 2014 
Wholesale fish markets in almost all cities and towns are operated by the municipalities concerned under the Ministry of Local Government. The wholesaling facilities in the municipal markets are generally inadequate for handling a highly perishable commodity like fish. In major cities like Dhaka, Chittagong, Khulna and Rangpur as well as district towns, the retail markets are managed by the municipalities. Conditions in these markets are also not adequate in respect to sales areas, parking, sanitation, water supply, drainage, cleaning and washing, maintenance and repairs. Sixty two percent of fish traders claimed this as a great problem for marine fish marketing.

\subsubsection{Lack of ice factories}

There is no recent information on the supply of ice. In 1992-93, there were 217 ice plants (block and flake) with a combined daily capacity of 4405 ton, located in the coastal districts of Chittagong, Barisal, Cox's Bazar, Patuakhali, Pirojpur, Khulna, Bagerhat and Noakhali. The supply of ice is limited, particularly during the peak fishing season. Shortage of ice during the peak season is reflected by the price charged. Most places do not have facilities for ice. These traders bring collected fish to landing centers in large cities. Most of the traditional boats fish inshore and stay out for one or two days and do not use ice to preserve the fish. The fish traders usually transport ice from distant places and often the use of ice is not adequate. A large number of fish traders own motorized fish transportation boats wherein they carry ice and collect catches from the fishers operating in coastal areas. Fifty four percent respondent claims that they are in trouble for shortage of ice.

\subsubsection{Lack of specialized cold storage}

There is also a lack of specialized cold storage at the marine fish landing centers. As fish is a very perishable product its need specialized cold storage to preserve. In peak season a large amount of marine fish are caught in the coastal belt of Bangladesh but for shortage of specialized cold storage it is not possible to preserve properly. Thirty nine percent respondents claimed that it's a problem in marine fish marketing system.

\subsubsection{Lack of credit facilities}

Financial help is required to run any business. But there is a little scope of institutional credit in fishing business. Lack of credit was reported as one of the problem by $38 \%$ respondent. They reported that when they were in need of fisheries loan, they did not get any major help from institutional sources. They also reported that bank credit process was very much complicated to get it in time.

\subsubsection{Lake of refrigerated vans}

There is a very limited facilities have been developed to transport marine fish by refrigerated vans to markets although it's a very effective to keep good quality of fish. In most cases marine fishes are transported by truck from landing centers to wholesale market. Twenty seven percent of respondents claimed that it's a problem of marine fish marketing chain.

\subsubsection{Lack of qualified staff for quality control and inspection}

To ensure better quality of marine fish, it is an argent need of inspection at all stages from harvesting to final consumer by DoF's efficient and specialized quality control officers. But in practical, there is a great shortage of quality control officers of DoFs as well as inspection office. For these reason it is not possible to ensure quality fish in marine fish marketing channels. Twenty one percent respondents claimed it's a problem in marine fish marketing chain.

\subsubsection{Limited market information}

Market information plays an important role for efficient marketing system. Timely and adequate market information is required for efficient operating system. Fifteen percent traders of marine fish claimed that they do not get the correct market information in time. 
Table 4. Problems and constraints of Marine fish marketing in Bangladesh

\begin{tabular}{lc}
\hline Problems and constraints & $\begin{array}{c}\text { Percentage of respondent } \\
\text { reported }\end{array}$ \\
\hline Post-harvest loss & 84 \\
Poor physical facilities for marketing of fish landing centers & 73 \\
Poor transport system & 68 \\
Inadequate facilities of wholesale and retail market & 62 \\
lack of ice factories & 54 \\
Lack of specialized cold storage & 39 \\
Lack of credit facilities & 38 \\
Lake of refrigerated vans & 27 \\
lack of qualified staff at DoF's quality control and inspection office & 21 \\
Limited market information & 15 \\
\hline
\end{tabular}

Source: Field survey 2014

\section{Conclusions}

This study explored marketing margin, profit and problems of marine fish marketing in Bangladesh and revealed that there is variation in profit earned by different intermediaries in the primary and secondary markets. In this regard primary and secondary markets should be free from control of beparies and aratders to make market competitive so that marine fishermen receive reasonable price to increase their sales revenue. The marketing system of marine fish in Bangladesh is yet not developed and it usually organized and managed by the private sector and face a lot of problems Among the problems of marine fish marketing post-harvest loss, physical facilities of landing center and transport system are the major problems. It is therefore, necessary to provide institutional and organizational support, government support, extensions cervices, and more research and knowledge of fish marketing. In addition, the establishment of modern wholesale markets in large urban areas, and establishment of well-functioning assembly markets at important fish landing sites may help sustainable fish marketing systems in coastal Bangladesh.

\section{References}

Ahmed, M., Rab, A. and Bimbao, M.P. 1993. Household socioeconomics, resource use and fish marketing in two Thanas in Bangladesh. ICLARM Tech. Rep., 40. $82 \mathrm{p}$.

BBS, 2015. Statistical Yearbook. Bangladesh Bureau of Statistics, Statistics Division, Ministry of Planning, Government of the People's Republic of Bangladesh, Dhaka

Chowdhury, N.K., Kompas T. and Kaliranjan K. 2010. Input and Quality Controls: A stochastic Frontier Analysis of Bangladesh's Industrial Trawl Fishery, AARES 54th Annual Conference 2010.

Chowdhury, M.H. 2004. Fish market and marketing issues in Bangladesh. In Proceedings of the Twelfth Biennial Conference of the International Institute of Fisheries Economics and Trade (eds. Y. Matsuda and T. Yamamoto), July 20-30, 2004, Tokyo, Japan.

Crawford, I.M. 1997. Agricultural and Food Marketing Management. Food and Agricultural Organization of the United Nations, Rome, 261-262. 
DOF, 2014. Fisheries statistical yearbook of Bangladesh 2012-2013. Department of Fisheries, Ministry of Fisheries and Livestock, Dhaka.

HIES, 2010. Preliminary report of Household Income and Expenditure Survey. Bangladesh Bureau of Statistics, Ministry of Planning, GoB, Dhaka.

Hossain, M.G. and Hoq, M.E. 2010. Sustainable Management of Fisheries Resources of the Bay of Bangal- Compilation of national and regional workshop reports. Support to Sustainable Management of the BOBLME Project. Bangladesh Fisheries Research Institute. SBOBLMEP pub/rep 2, 122 p.

Islam, M.S. and K.Q. Elahi. 1993. Small Scale Marine Fisheries in Bangladesh: A Socioeconomic Analysis, Research Report No. 23. Bureau of Socioeconomic Research and Training, BAU, Mymensingh.

Islam, M.S., Miah, T.H. and Haque. 2001. Marketing System of Marine Fish in Bangladesh: An Emperical Study. Bangladesh J. Agric. Econs. XXIV 1 \&2 (2001):127-142.
Kawarazuka and Béné, 2010. Linking smallscale fisheries and aquaculture to household nutritional security: an overview. Food Security, 2: 343-357.

Kawarazuka and Béné, 2011. The potential role of small fish species in improving micronutrient deficiencies in developing countries: building evidence. Public Health Nutrition. 2011 14(11):1927-38.

Kohls and Uhl, 2005. Marketing of Agricultural Products. Macmillan Publishing Co., Inc., New York.

Mazid, M.A. 2005. Manual on Culture of Small and Threatened Indigenous Fish Species. Bangladesh Fisheries Research Institute, Department of Fisheries, Bangladesh Agricultural University, and Ministry of Fisheries and Livestock

Minkin, S,1., Stephen, F. M., Rahman, M. and Halder, S. 1997. Inland Capture Fisheries of Bangladesh, University Press Limited, Dhaka

Roos, N., Wahab, M.A., Chamnan. C., and Thilsted. S.H. 2007. The role of fish in food-based strategies to combat vitamin A and mineral deficiencies in developing countries. Journal of Nutrition 137:11061109 